\title{
Do Board's Corporate Social Responsibility Strategy and Orientation Influence Environmental Sustainability Disclosure? UK Evidence
}

\author{
Akrum Helfaya ${ }^{1}{ }^{2}$ \\ Keele University, UK \& Damanhour University, Egypt \\ Email: a.n.ekara.helfaya@keele.ac.uk \\ Tantawy Moussa ${ }^{2}$ \\ University of Westminster, UK \& Cairo University, Egypt \\ Email: moussat@westminster.ac.uk
}

This is the final peer reviewed version of the following paper: [Helfaya, A., \& Moussa, T. (2017). Do Board's Corporate Social Responsibility Strategy and Orientation Influence Environmental Sustainability Disclosure? UK Evidence. Business Strategy \& the Environment], which has been published in final form at [DOI:10.1002/bse.1960]. This paper may be used for non-commercial purposes in accordance with John Wiley \& Sons, Ltd and ERP Environment terms and conditions for self-archiving.

\footnotetext{
${ }^{1}$ Corresponding Author

${ }^{2}$ Both authors contributed equally to this paper
} 


\title{
Do Board's Corporate Social Responsibility Strategy and Orientation Influence Environmental Sustainability Disclosure? UK Evidence
}

\begin{abstract}
The environmental implications of corporate economic activities have led to growing demands for firms and their boards to adopt sustainable strategies and to disseminate more useful information. This paper investigates the impact of board's corporate social responsibility (CSR) strategy and orientation on the quantity and quality of environmental sustainability disclosure in UK listed firms. We find that effective board's CSR strategy and CSR-oriented directors have a positive and significant impact on the quality of environmental sustainability disclosure, and not on the quantity. Our findings also suggest that the existence of a CSR committee and issuance of stand-alone CSR report are positively and significantly related to environmental sustainability disclosure. When we distinguish between firms with high and low environmental risk, we find that the board CSR practices that affect the quantity 2(quality) of environmental sustainability disclosure appear to be driven more by highly (lowly) environmentally sensitive firms. These results suggest that board's sustainability practices play an important role in ensuring a firm's legitimacy and accountability towards stakeholders. Our findings shed new light on this under-researched area and could be of interest to companies, policy-makers, and other stakeholders.
\end{abstract}

Keywords: Environmental sustainability disclosure, board corporate social responsibility strategy, board corporate social responsibility orientation, corporate social responsibility committee, UK. 


\section{Introduction}

The environmental implications of corporate economic activities have led to growing demands on firms to adopt sustainable strategies and to disseminate more relevant and reliable information on their environmental performance (Alberici and Querci, 2016; Arena et al., 2015; D'Amico et al., 2016; Shaukat et al., 2016). Corporate Environmental Sustainability Disclosure (CESD) can typically be defined as the process of disseminating information related to a company's activities, aspirations, and public image with regard to environmental sustainability matters (Gray et al., 2001). In practice, CESD practices are affected by the motives and values of corporate directors involved in formulating and setting environmental policies and strategies (Lock and Seele, 2015; Neugebauer et al., 2016; Solomon and Lewis, 2002). Thus, board-level governance can play an important role in enhancing CESD practices (Khan et al., 2013; Michelon et al., 2015; Prado-Lorenzo and Garcia-Sanchez, 2010). These CESD practices indicate an effective corporate commitment to environmental responsibility and construct a firm's image of environmental performance designed to positively manage stakeholders' perceptions and to legitimise its existence (Clarkson et al., 2008; Fifka, 2013; Mallin et al., 2013).

Although Corporate Governance (CG) and Corporate Social Responsibility (CSR) reporting practices have been well researched as separate topics, few studies have investigated their interrelationship (Galbreath, 2010; Landry et al., 2016; Jizi et al., 2014; Schwartz, 2005; Seto-Pamies, 2015). In particular, prior research largely neglects investigating whether board's CSR strategy and orientation have influence on CESD practices. This paper fills this literature gap by investigating the influence of (i) board's CSR strategy, (ii) board's CSR orientation, (iii) the existence of CSR committee, and (iv) the issuance of a stand-alone CSR report on the quantity and quality of CESD.

Our results indicate that effective board's CSR strategy and CSR-oriented directors (i.e., boards with more independent directors, female directors and audit committees' directors with financial expertise) have a positive and significant effect on the quality of CESD, rather than its quantity. Moreover, the existence of CSR committee and issuance of stand-alone CSR reports are positively and significantly related to CESD. Interestingly, when we differentiate between firms with high- and low- environmental risk, we find that the boardlevel CSR attributes affecting the quantity (quality) of CESD appear to be driven more by 
highly (lowly) environmentally sensitive firms. These results lend support to legitimacy, stakeholder, and resource dependence theories. Thus, our paper extends the applicability and predictive power of these complementary and overlapping theories.

This paper differs from prior research, and contributes to the literature in various ways. First, to the best of our knowledge, this is the first study to examine how effective board's CSR strategy and orientation can contribute to safeguarding stakeholders' interests via disseminating relevant and credible CESD. It also directly responds to the call for developing a better understanding of board attributes and CESD practices (Liao et al., 2015; Lock and Seele, 2015; Michelon et al., 2015). Second, this paper is innovative in employing a less subjective multi-dimensional quality model (MQM) for assessing the quality of CESD. This MQM goes beyond the more traditional author-based disclosure index, focusing on preparerand user-based index that assesses the quality of environmental information (Beck et al., 2010; Helfaya, 2012; Helfaya and Kotb, 2016). Third, our results suggest that firms with high levels of board's CSR strategy, CSR-oriented board, the existence of CSR committee, and publishing stand-alone reports are more likely to disclose more relevant and credible environmental information to gain its legitimacy and stakeholders' satisfaction. This may have important policy and regulatory implications (Khan et al., 2013; Landry et al., 2016; Seto-Pamies, 2015).

The remainder of the paper is structured as follows. Section 2 presents a multi-theoretical framework. Section 3 provides the literature review and hypotheses development, and Section 4 outlines research design. Section 5 discusses results, and Section 6 concludes the study.

\section{A multi-theoretical perspective for CESD}

CESD research has significantly increased over the last two decades with most of which relying largely on a single theoretical perspective, such as legitimacy, agency, stakeholder, resource dependence, institutional, and impression management theories (Alrazi et al. 2016; Chen and Roberts, 2010; Deegan et al., 2002; Cooper and Slack 2015; Mallin and Michelon, 2011; Shaukat et al., 2016), which limits our understanding of CESD practices (Gray et al., 1995; Haque et al., 2016). In contrast, this paper adopts a multi-theoretical perspective (i.e. 
legitimacy, stakeholder and resource dependence) as complementary rather than competing theories, to provide a richer basis for understanding and explaining the CESD behaviour.

Legitimacy theory proves that firms can gain social acceptance and legitimise their existence by engaging in CESD (Cho and Patten, 2007; Chen and Roberts, 2010; Deegan et al., 2002; Mallin and Michelon, 2011). According to Suchman (1995), corporate legitimation strategies are used to gain and maintain legitimacy (i.e., proactive strategy by good performer [the good apple]) or to repair legitimacy after a specific environmental accident (i.e., reactive strategy to clear the bad image by bad performer [the bad apple]) (Cho, 2009; Menguc et al., 2010). These two legitimacy strategies, therefore, are used by firms to disclose information about their environmental performance and strategies to different stakeholders, to offset negative media coverage about current environmental crises and to purify this bad reputation ( $\mathrm{Lu}$ and Abeysekera, 2014; Samkin and Schneider, 2010; Schwartz, 2005).

Stakeholder theory is concerned with the impact of environment on firms and focuses on the firms and its various stakeholders who form this environment (Deegan, 2007; Godfery et al., 2010). Stakeholder theory also recognises that the influence of each stakeholder on the firm is dissimilar, and the expectations of different stakeholders are diverse and sometimes conflicting (Chen and Roberts, 2010). Thus, to receive the support from its stakeholders, firms need to have a dialogue with them to balance these conflicting expectations. CESD is, therefore, seen as part of this dialogue between firms and their stakeholders (see, Deegan and Unerman, 2006)

Finally, and closely connected with legitimacy and stakeholder theories, resource dependence theory (RDT) considers CESD as a tool to manage a company's image through communicating its output, goals, or methods of operations, and to enhance its legitimacy (Casciaro and Piskorski, 2005; Davis and Cobb, 2010; Hillman et al., 2009; Schnittfeld and Busch, 2016). It focusses on the effect of the environmental constraint on organisation and its engagement in exchanges and transections with other entities for various resources (Hillman et al., 2009; Pfeffer and Salancik, 1978; Schnittfeld and Busch, 2016). RDT has been recently used to explain the role of the board of directors in achieving corporate sustainable developments (e.g., Casciaro and Piskorski, 2005; Mallin et al., 2013; Shaukat et al., 2016). It views the board as a resource for managing and controlling a company's external environmental risks (Pfeffer and Salancik, 1978). Hillman and Dalziel (2003) suggested that 
the key resource dependence related contributions of the board are enhancing corporate legitimacy, providing expertise and advice, formulating corporate strategy, facilitating access to resources and building good external relation with various stakeholders (Casciaro and Piskorski, 2005; Davis and Cobb, 2010; Hillman et al., 2009).

The connection and basic assumptions used by the three theories explained above are that firms operate in a society that affects their practices, since the society has resources that firms want (Chen and Roberts, 2010; Hillman et al., 2009). To receive these resources, firms have to meet the society's expectations. Thus, CESD can be used to convince the society that firms act in accordance with that society's expectations. In CESD literature, scholars have applied many theories, and in this regard Gray et al. (1995) and Chen and Roberts (2010) argued that it is not possible to explore CESD by using a single theory. With this in mind, this study used these three overlapping theories to give complementing investigation into the impact of board's CSR strategy and orientation on CESD.

\section{Literature review and hypotheses development}

\subsection{Board's CSR Strategy}

Only few of CSR-related studies have identified the variables of capturing a company's board strategy towards its environmental responsibilities (Shaukat et al., 2016). According to Banerjee et al. (2003, p. 106), environmental strategy is "the extent to which environmental issues are integrated into a firm's strategic plans" to gain a competitive advantage. The board of directors is responsible for setting the environmental strategy and overseeing its implementation to make a positive impact on the environment (Fraj-Andrés et al., 2009; Hart, 1995). RDT indicates that the firms' specific resources, such as financial, manufacturing and board-level human's vision and strategies could be used to create sustainable competitive advantages, compared to their peers (Shaukat et al., 2016; Hillman et al., 2009; Casciaro and Piskorski, 2005). Additionally, legitimacy and stakeholder theories highlight the importance of communicating these proactive environmental strategies to external stakeholders to gain social legitimacy (e.g., Martensson and Westerberg, 2016; Neugebauer et al., 2016; Shaukat et al., 2016). Empirically, and consistent with the theoretical predictions, Al-Tuwaijri et al. (2004) and Clarkson et al. (2011) prove that to achieve the firm's long-term interest, good management adopts proactive strategies for controlling environmental pollution. Moreover, Shaukat et al. (2016) find that firms with more proactive and comprehensive the firm's CSR 
strategy are likely to show better environmental performance to gain competitive advantage in the long-term. Accordingly, we frame our first hypothesis as follows:

H1a. The quantity of CESD is positively associated with the effectiveness of board's CSR strategy.

H1b. The quality of CESD is positively associated with the effectiveness of board's CSR strategy.

\subsection{Board's CSR Orientation}

Banerjee et al. (2003, p.106) define CSR orientation as "the recognition by directors to the importance of environmental issues facing their firms". In this context, Shaukat et al. (2016) find that board's CSR orientation boosts the firm's CSR activities and environmental performance. Previous studies suggest that board attributes may be present amongst directors who have a positive effect on firm's CESD, such as board independence, gender diversity, and audit committee financial expertise. This study follows, among others, Liao et al. (2015) and Shaukat et al. (2016) in using several board-specific characteristics (i.e. board independence, board gender diversity, and audit committee financial expertise) to capture the board's CSR orientation.

\section{Board Independence}

Although, there is a lawful responsibility on all corporate directors to execute in the best interests of all stakeholders, this does not assure that directors will execute objectively. To achieve this objectivity, the UK CG Code (2014) requires a sufficient number of board members to be independent of management. The UK CG Code states that board independence means that there are no contractual relationships or circumstances that may affect its director's judgement (see, FRC, 2014, para. B.1.1). According to RDT and legitimacy-stakeholder framework, independent directors attract invaluable resources to their companies by having external dialogues with stakeholders and other organisations and enhancing their reputations (Arena et al., 2015; Haniffa and Cooke, 2005; Mallin and Michelon, 2011). A number of studies (e.g., Chau and Gray, 2010; Cheng and Courtenay, 2006; Harjoto and Jo, 2011; Jizi et al., 2014) document that independent boards are greatly engaged in CSR reporting to promote stakeholders' interests, and to facilitate a comparatively high degree of transparency and CESD. Accordingly, we argue that independent directors are more likely to focus on long-term financial performance goals and offer effective monitoring on environmental matters which in turn improve long-term sustainability. 


\section{Board Gender Diversity}

Boardroom diversity, particularly gender diversity, is high on the agenda in the UK and in Europe (FRC, 2011). It is increasingly recognised that women can make a significant contribution to a board, especially in relation to social and environmental matters (Ben-Amar et al., 2016; Liao et al., 2015; Landry et al., 2016; Post et al., 2011). The role of female directors was explained from different perspectives. First, there is a general consensus that female directors are more stakeholder-oriented and more sensitive to CSR issues, which in turn may support mechanisms of stakeholder engagement, and promote CESD practices (AlShaer and Zaman, 2016; Landry et al., 2016; Liao et al., 2015; Seto-Pamies, 2015). Second, female directors are more averse to litigation and reputation loss, which in turn could motivate them to take actions to get engaged in sustainable corporate initiatives and minimising perceived environmental risks (Srinidhi et al., 2011). Third, female directors bring diverse perceptions and values to the boardroom, encourage democratic and participative decision-making, and broaden discussions to better represent the concerns of stakeholders, leading to an improvement in the firm's dedication towards CSR activities (Bear et al., 2010; Nielsen and Huse, 2010). Accordingly, we argue that a gender-diverse board may affect CESD due to females' higher concerns of environmentally sustainable initiatives and greater empathy towards stakeholder issues.

\section{Audit Committee Financial Expertise}

Owing to the increasing complexity of accounting and auditing information, the expertise of audit committee serves as a valuable instrument in eliminating financial misstatements (Beasley et al., 2009) and enhancing the quality and credibility of corporate reporting (Chen et al., 2006; Smith, 2003; FRC, 2014). In the same way, environmental risks can have significant financial implications, such as environmental fines, litigation costs and potential cash outflows for environmental maintenance. Audit committee members with financial literacy are likely to be qualified for advising the board to avoid and manage these risks in both short- and long-term. Recently, Khan et al. (2013) find that the existence of an audit committee on the board has a positive and significant impact on CSR disclosures. Accordingly, to improve the quality of CSR disclosure practice, financial experts on audit committees can inspire their companies to apply CSR reporting guidelines, set a CSR committee, hire a CSR Officer, publish stand-alone CSR reports, etc. (Khan et al., 2013; Peters and Romi, 2014; Rodrigue et al., 2013). This, therefore, supports the argument that audit committee financial expertise could enhance CESD. 
Based on the above discussion, we expect a positive relationship between board's CSR orientation and CESD. Thus, our second hypothesis is that:

H2a. The quantity of CESD is positively associated with board's CSR Orientation.

H2b. The quality of CESD is positively associated with board's CSR Orientation.

\subsection{CSR Committee}

One of the main CG mechanisms is setting a specific committee (e.g., CSR committee) $)^{3}$ to manage environmental issues from the perspectives of risks, strategic opportunities, meeting corporate sustainable goals, and commitments to stakeholders (Peters and Romi, 2015). Rodrigue et al. (2013) examine whether CSR committee does a substantial or symbolic role on environmental performance and disclosure. They assert that such committees emphasise avoiding reputational risk and litigation cost, and this affects the level of CESD. Among others, Liao et al. (2015) and Peters and Romi (2014) investigate the association between the presence of CSR committee and greenhouse gas emissions (GHG) disclosure. They find that GHG disclosure is positively related to the presence of CSR committee. In light of the above discussion, we expect that CSR committee is more likely to respond to stakeholders' demands for more CESD. Therefore, our third hypothesis is that:

H3a. The quantity of CESD is positively associated with the existence of CSR committee.

H3b. The quality of CESD is positively associated with the existence of CSR committee.

\subsection{Issuance of Stand-alone CSR Reporting}

CSR reporting is the process of disseminating information on the social and environmental performance in corporate annual reports, stand-alone reports and/or websites (Guthrie et al., 2008; Robertson and Samy, 2015). CSR literature states that environmental reporting helps companies to resolve some of their damaged reputation and environmental problems and sustain good relationships with relevant stakeholders (e.g., Chauvey et al., 2015; Patten and Zhao, 2014). Similarly, prior surveys in CSR reporting practices show a large increase in publishing stand-alone CSR reports which include environmental information (KPMG, 2013; Michelon et al., 2015). For example, KPMG Survey (2013) report that the average

\footnotetext{
${ }^{3}$ We are using CSR committee as a catchall name of such board committee. This committee may also be referred to as "social responsibility", "sustainability", "corporate ethics", "environmental", "health and safety", "sustainable development" committee.
} 
sustainability reporting rate of the 100 largest companies in 41 countries (N100) has increased from $64 \%$ in 2011 to $71 \%$ in 2013. Empirically, Dhaliwal et al.'s claim that the issuance of a stand-alone CSR report is viewed as a sign of the quality of disclosure because it provides relevant and material information for investors to assess firms' CSR performance (Dhaliwal et al., 2012, 2014). Other scholars argue that CSR reports are little more than public relations mechanisms developed by firms to legitimatise their existence (Unerman et al., 2007) or to manage the perceptions of the stakeholders (Thorne et al., 2014). Based on the above debate, our final hypothesis is that:

H4a. The quantity of CESD is positively associated with the issuance of stand-alone CSR report.

H4b. The quality of CESD is positively associated with the issuance of stand-alone CSR report.

\section{Research Design}

\subsection{Sample and Data Collection}

Our sample comprises firms listed on the UK FTSE 100 for the fiscal year 2010; the FTSE 100 is one of the globe's best-known stock market indices and a bellwether for the UK economy. The UK was chosen because it has experienced high levels of environmental reporting practices (KPMG, 2013; Michelon et al., 2015). We investigate environmental disclosure by analysing corporate stand-alone CSR reports, and when they were not publicly available, annual reports were used. Data on environmental governance and financial variables were manually collected from company annual reports or DataStream database. To ensure comparability of the results, companies with complete data for all study variables were used which led to a total sample of 94 firms. The sample distribution is presented in Table 1 .

\section{<INSERT TABLE 1 HERE >}

\subsection{Dependent variables - CESD disclosure}

To quantify CESD, we developed a disclosure index based on the Global Reporting Initiative (GRI) sustainability reporting guidelines as an international benchmark (GRI, 2006) and prior stuides. This index consists of 32 environmental disclodure items and six environmental categories: (1) environmental policy; (2) energy, and raw materials used (inputs); (3) environmental product- and process-related data (outputs); (4) environmental- 
financial data; (5) climate change and sustainability; and (6) environmental others (This appendex is available upon request). We then employed the widely used content analysis method to analyse CESD; this may include: page, paragraph, sentence or word counts (Beattie et al., 2004; Gray et al., 1995; Martinez-Ferrero et al., 2016). Notwithstanding words and sentences count often being used as the most appropriate measures for determining the quantity, the assessment still resulted in non-narrative disclosures such as pictures, graphs, or charts being ignored (Van Staden and Hooks, 2007), thus producing an inaccurate picture of the reporting. This study, therefore, scores the quantity of CESD (QUAN_ED) using the proportion of the page that coveys the space given to each environmental theme/item, reflecting the relative importance of reported theme(s).

For assessing the quality of CESD (QUAL_ED), we used a less subjective multi-dimensional quality model (MQM) developed by Helfaya (2012) for assessing the quality of environmental discourse. This MQM goes beyond the more traditional author-based disclosure indices, focusing on preparer- and user-based index that assesses quantity of CESD and captures a high level of content, credibility and communication of environmental information. The MQM measures the quality of CESD depending on three different complementary dimensions (3Cs): first, Content - CON_ED (weighted 56\%) including four sub-dimensions: quantity (10\%), themes (14\%), measures of disclosure (16\%), and types of information (16\%). Second, Credibility - CRE_ED (weighted 31\%) including two subdimensions: adopting external reporting guidelines (16\%), and including third-party assurance (15\%). Third, Communication - COM_ED (weighted 13\%) including three subdimensions: tables (4.60\%), graphs (4.40\%), and images $(4 \%)$.

Following MQM, we assigned a score for each sub-dimension of information as a preliminary process to calculate the quality disclosure score (QUAL_ED). Other than the quantity sub-dimension, the quality sub-dimensions were assessed using the developed index. Except for sub-dimensions of communication quality, a binary variable was used ( 1 or 0 , depending on whether the item was disclosed or not). The total quality disclosure score is calculated by using the following formula and is then expressed as a percentage, ranging from the lowest $(0 \%)$ to the highest $(100 \%)$ :

$$
\mathrm{QUAL}_{\mathrm{E}} \mathrm{D}_{\mathrm{i}}=\sum\left(\mathrm{CON} \_\mathrm{ED}_{\mathrm{i}}+\mathrm{CRE} \_\mathrm{ED}_{\mathrm{i}}+\mathrm{COM} \_\mathrm{ED}_{\mathrm{i}}\right)
$$


To enhance reliability of the research index, a preliminary check was performed on a sample of nine annual documents (Krippendorff, 2004). Coding was undertaken by the first researcher and was assessed by the second researcher for achieving greater accuracy and consistency (Krippendorff, 2004). The Cronbach's Alpha was also calculated to assess the internal consistency reliability of CESD scores (89.3\%), which is above the appropriate minimum acceptable level (70\%) (Cavana et al., 2001).

\subsection{Independent variables}

The independent variables in our analysis are: board's CSR strategy, board's CSR orientation, CSR committee, and issuance of a standalone CSR report. We measure board's CSR strategy (BCSRS) through a board CSR strategy index developed by Thomson Reuters ASSET4 database. The index captures firm-level CSR policies and initiatives, with higher CSR strategy score indicating greater CSR-related activism of a firm and hence more proactive is its board-level CSR planning, oversight, and communication strategy. Following recent studies (Qiu et al., 2016 and Shaukat et al., 2016), we used the ASSET4 scores, namely indicators related to board strategy, which are regarded as one of the comprehensive leading databases on corporate social, environmental and governance information.

Additionally, we include board's CSR orientation (BCSRO) which is a composite measure consisting of board independence (INDED), board gender diversity (FEMD) and audit committee financial expertise (ACFEX). Board independence is a dummy variable equal to 1 if the majority of board members are independent and 0 otherwise. Gender diversity on the boards is a dummy variable equal to 1 when there is at least one female director on board and 0 otherwise. Audit committee financial expertise is a dummy variable equal to 1 when there is at least one member of the committee having financial expertise and 0 otherwise. Therefore, BCSRO uses a score of $0-3$ to provide an indicator of the board-level CSR orientation. We also include CSR committee (CSRC) which is a dummy variable equal to 1 if a CSR committee exists and 0 otherwise. Stand-alone CSR report (SCSRR) is a dummy variable equal to 1 if the company issues a standalone CSR report and 0 otherwise.

\subsection{Control variables}

To avoid model misspecification, we control for additional variables that could influence the CESD practices. Following prior literature, we control for firm size (FSIZE) which is measured as the natural log of total assets (see D'Amico et al., 2016; Liao et al., 2015; 
Tauringana and Chithambo, 2015). We also control for firm profitability, measured by return on assets (ROA) (Brammer and Pavelin, 2008; Clarkson et al., 2011). We account for the effect of firm leverage (LEV) on disclosure practices, measured through the ratio of long term debt to total assets (D'Amico et al., 2016). In line with prior research (Tauringana and Chithambo, 2015), we also control for the effect of financial slack (SLACK). Firms with higher financial slack (measured as cash \& short term investments, divided by total assets) are likely to invest in socially responsible activities, including CESD. Moreover, capital expenditure (CAPEX), the ratio of capital expenditure to total assets, is also considered to be a factor that could affect the CESD (de Villiers et al., 2011; Tauringana and Chithambo, 2015).

Furthermore, we control for block shareholdings (SHOLD) which are measured as shareholdings of $5 \%$ or more. There is evidence suggesting that block shareholdings tend to further their own interests, rather than the interests of other stakeholders, leading to a decline in CSR related activism (Shaukat et al., 2016). Accordingly, we expect negative association between block shareholdings and CESD. We also control for CEO duality (i.e. a dummy variable that equals 1 if the CEO simultaneously serves as the chairman and 0 otherwise). Finally, we also controlled for industry classification (IND) (ten groups).

\subsection{Empirical model}

We develop the following empirical model to test our hypotheses,

$$
\begin{aligned}
Q U A N_{-} E D, Q U & A_{-} E D, C O N_{-} E D, C R E \_E D, C O M_{-} E D \\
& =\alpha+\beta_{1} B C S R S+\beta_{2} B C S R O+\beta_{3} C S R C+\beta_{4} S C S R R+\beta_{5} S H O L D \\
& +\beta_{6} D U A L I T Y+\beta_{7} F S I Z E+\beta_{8} R O A+\beta_{9} L E V+\beta_{10} S L A C K \\
& +\beta_{11} C A P E X+\beta_{12} I N D+\varepsilon
\end{aligned}
$$

where QUAN_ED is the quantity of CESD score, QUAL_ED is the quality of CESD score, CON_ED is the content sub-index of CESD quality, CRE_ED is the credibility sub-index of CESD quality, COM_ED is the communication sub-index of CESD quality, BCSRS is board's CSR strategy, BCSRO is board's CSR orientation, CSRC is CSR committee, SCSRR is the issuance of a standalone CSR report, SHOLD is the block shareholdings, DUALITY is the CEO duality, FSIZE is the firm size, ROA is the return on assets, LEV is the firm leverage, SLACK is the financial slack, CAPEX is the capital expenditure, INDU is the industrial membership, and $\varepsilon$ is the error term. The analysis is carried out using the OLS 
regression model. We also used the robust standard errors to ensure robust and valid statistical inference (Hoechle, 2007).

\section{Results and discussions}

\subsection{Descriptive statistics and univariate analysis}

Table 2 reports the descriptive statistics for all variables used in the regression model. It is evident that the firms disclosed, on average, $24.15 \%$ of the total report pages on CESD, with a minimum of $0.17 \%$ and a maximum of $100 \%$, indicating wide variation in the quantity environmental disclosure (QUAN_ED). We also find that the mean CESD quality score (QUAL_ED) is $46.08 \%$, with disclosures ranging from $9.16 \%$ to a maximum of $83.99 \%$, indicating that the quality of CESD by FTSE 100 companies is still low. A review of the quality disclosures with respect to the three sub-indices indicates that the quality of content (CON_ED), on average, is 26.68 out of 56, indicating that the content of CESD is largely non-financial and qualitative in nature with little use of different environmental themes, quantitative measures and different types of information (bad news, future looking information, etc.). Similarly, the credibility of CESD (CRE_ED), on average, is 15.68 out of 31 , suggesting most of the firms adopted sustainability reporting guidelines or used assurance services. Interestingly, for the use of communication tools (e.g., graphs, tables and images), it seems that most of the CESD content is textual rather than visual (the average level of disclosure for COM_CD = 3.72 out of 13). These findings provide support for past evidence (Alrazi et al., 2016; Tauringana and Chithambo, 2015), which that firms tend to disclose primarily non-financial and qualitative environmental information to gain and maintain corporate legitimacy.

Table 2 further shows that the mean value of board's CSR strategy (BCSRS) is $84.35 \%$. We also find the board's CSR orientation (BCSRO) ranging from 0 to 3 with an avrage of 2.104. The mean values of independent directors (INDED) and financial expertise on audit committees (ACFEX) are 56.01\% and 65.4\%, respectively. This is similar to Shaukat et al. (2016) who reported a mean of $52 \%$ board independence and $65 \%$ of audit committees having financial expertise. With regard to board gender diversity, we find the the percentage of female directors on boards (FEMD) is $12.6 \%$. This is lower than the $14.1 \%$ reported in AlShaer et al. (2016) for their sample of 2012 FTSE350 firms, indicating that there has been a gradual increase in the percentage of women on boards in 2012 compared to 2010. We also 
find that on average, $68.75 \%$ of firms have a CSR committee (CSRC) and $74.75 \%$ of firms publish standalone CSR report (SCSRR). In addition, the mean value for block shareholdings (SHOLD) is $14.27 \%$, CEO duality (DUALITY) is $2 \%$, firm size (FSIZE) is $£ 89.05$ million, profitability (ROA) is $6.76 \%$, leverage (LEV) is $18.15 \%$, firm financial slack (SLACK) is $11 \%$, and capital expenditure (CAPEX) is $4.17 \%$.

\section{<INSERT TABLE 2 HERE>}

Table 3 shows the correlation matrix for variables used in our analysis. It is evident that quantity and quality of CESD are significantly and positively related to all independent variables, supporting hypotheses 1, 2, 3 and 4. Table 3 further shows low correlations among all the independent variables, implying that multicollinearity is unlikely to be a concern. We also examine the variation inflation factors (VIF) to test for the existence of multicollinearity (Gujarati, 2003). The results indicate that the VIF values are below 10, suggesting no serious collinearity in the examined models.

\section{〈INSERT TABLE 3 HERE>}

\subsection{Multivariate regression analyses}

Table 4 shows the regression results examining the impact of board's CSR strategy, board's CSR orientation, CSR committee and issuance of stand-alone CSR report on the quantity and quality of CESD.

\subsubsection{Board's CSR strategy (H1)}

The results show that board's CSR strategy score has a significant and positive association with both CESD quality and credibility, but is not significantly associated with the quantity, content or communication of CESD. This only supports hypothesis $H 1 b$ of a positive relationship between board's CSR strategy and the quality of CESD. Our evidence suggests that that firms respond to increased stakeholders' expectation through developing a proactive and comprehensive board's CSR strategy, which in turn leads to greater CSR-related activism and CESD quality. Specifically, we find boards with effective CSR strategy tend to disclose more reliable and useful environmental information to stakeholders through the use of the GRI guidelines and independent external assurance. This result is consistent with the findings 
of previous studies (e.g., Al-Tuwaijri et al., 2004; Clarkson et al., 2011; Hart, 1995; Martensson and Westerberg, 2016) that indicate that CSR strategy has a positive effect on organisational outcomes. Shaukat et al. (2016) also find a positive association between firm's CSR strategy and environmental and social performance. It also provides further empirical support for our multi-theoretical framework that integrates insights from stakeholder, legitimacy, and RDT theories. For instance, board's CSR strategy can help to manage stakeholders' interests with regard to CSR disclosure (stakeholder theory), gain and maintain corporate legitimacy licences and reputation (legitimacy theory), and facilitate access to resources (RDT).

\subsubsection{Board's CSR orientation (H2)}

The results indicate a significant positive relationship between the composite measure of board's CSR orientation and the quality of CESD as well as its components (content, credibility and communication), rather than its quantity. This suggests that boards with more independent directors, female directors and audit committees' directors with financial expertise, are likely to adopt environmentally responsible activities and disclose higher quality of CESD. Hence, $H 2 a$ is rejected but $H 2 b$ is confirmed. This result is consistent with prior studies (e.g., Arena et al., 2015; Cheng and Courtenay, 2006; Hillman et al., 2002; Jo and Harjoto, 2011; Khan et al., 2013). Liao et al., (2015) found independent and diversified boards are positively associated with carbon disclosures. Al-Shaer and Zaman (2016) also found that gender diverse boards are associated with higher quality sustainability reports of UK firms. This evidence is consistent with the stakeholder theory in that diversified and independent boards and audit committees' directors with financial expertise are more likely to make a balance between a firm's financial and non-financial goals and put pressure on managers to respond to stakeholder concerns related to environmental activities (Deegan, 2007; Hanniffa and Cooke, 2005), and then disclose more useful environmental activities (Khan et al., 2013). Additionally, RDT suggests that more independent, female directors and audit committee directors' financial expertise can attract crucial resources such as human and relational capital, which in turn improves firms' long-term sustainability including CSR reporting.

\subsubsection{CSR committee and stand-alone CSR report (H3\& H4)}

The results indicate that the existence of CSR committee (CSRC) and the issuance of standalone CSR report (SCSRR) are positively and significantly associated with the quantity and 
quality of CESD and its content and communication but not significantly associated with the credibility of CESD, thus confirming hypotheses $\mathrm{H} 3$ and $\mathrm{H} 4$. A possible explanation is that the CSR committees are mainly responsible for overseeing the firm's management of CSR which might lead to more extensive CESD for the firm. Regarding the issuance of the standalone CSR report, the results support the notion that firms need to legitimise its performance and manage the perception of stakeholders (Michelon et al. 2015). This is consistent with previous studies (Dhaliwal et al., 2011, 2012, 2014; KPMG, 2013; Patten and Zhao, 2014). The positive relationship implies that the existence of CSR committee and publishing standalone CSR report are two of the main corporate environmental governance mechanisms to address environmental risks and engage with interested stakeholders (Mahoney et al., 2013; Peters and Romi, 2014, 2015). This, therefore, will lead to more emphasis on avoiding any reputational risk and expected litigation cost, and improving the quantity and quality of CESD. This result is in line with our multi-theoretical framework that suggests that firms adopt these CG mechanisms as public relations' tools to legitimise their existence (e.g., Mahoney et al., 20013; Mallin et al., 2013), and manage the perceptions of the relevant stakeholders (Thorne et al., 2014).

\section{〈INSERT TABLE 4 HERE〉}

\subsection{Additional analyses}

We carry out two additional analyses to ascertain the robustness of our results. Firstly, we further investigate the effect of board's CSR strategy and orientation on the quantity and quality CESD when corporate environmental risks differ. Prior empirical studies indicate that CESD is influenced by the level of environmental risk of companies (i.e. sensitivity to the environment) (Brammer and Pavelin, 2008; Cuganesan et al., 2010; Helfaya, 2012; Tauringana and Chithambo, 2015). Thus, we re-run Eq. (1) by splitting our sample into high environmentally sensitive industries (HESI) and low environmentally sensitive industries (LESI). A number of interesting results emerge from the additional analysis (not tabulated): First, and consistent with our findings in Table 4, BCSRS has a significant positive effect on CESD (i.e., quality and credibility) for LESI, but not significant for HESI. Second, CSR committee, with respect to HESI, is positively related to all disclosures, but only the coefficient on (QUAN_ED) is statistically significant. In contrast, the effect is positive and significant in LESI, implying that a board with CSR committee is more likely to provide a 
better connection with stakeholders, and enhance corporate legitimacy and reputation. These results also suggest that board's CSR strategy and CSR committee play a more pronounced CESD role by acting as a substitute for statutory control in LESI. Third, except for (CON_ED), board's CSR orientation (BCSRO) is significantly positively related to all disclosures in HESI, whereas in LESI the coefficient of BCSRO is significant with the quality and credibility of CESD. These results are consistent with stakeholder theory, suggesting that a strong board orientation toward environmental accountability is more likely to be more environmentally responsive, thereby leading to more CESD.

Secondly, to examine whether our results are sensitive to the board's CSR orientation proxy employed, we replicate our results in Table 4 by using an alternative measure which is a measure of the average of Z-scored of (i) \% of independent directors; (ii) \% of female directors; and (iii) \% of audit committee financial expertise. Noticeably, the results (not tabulated) are consistent with our earlier results.

\section{Conclusions}

This study investigates the effects of board's CSR strategy, board's CSR orientation, CSR committee and issuance of a stand-alone CSR report on the quantity and quality of CESD. Based on sample of the UK FTSE100 firms, we find that effective board's CSR strategy and CSR-oriented boards have a positive and significant impact on the quality of disclosure, rather than its quantity. Our findings also suggest that the presence of CSR committee and issuance of stand-alone CSR report are positively and significantly related to CESD. These results lend support to legitimacy, stakeholder and resource dependence theories (Mallin et al., 2013). For CSR-related RDT, the board of directors and sustainable strategies could be seen as unique governance mechanisms which help firms disclose high-quality information on environmental performance (Mallin and Michelon, 2011; Shaukat et al., 2016). Moreover, these board's attributes are more likely to seek environmental legitimacy and high stakeholders' satisfaction via disseminating useful environmental information (e.g., Axjonow et al., 2016; Michelon et al., 2015). This study contributes to the literature by providing empirical evidence of board's CSR strategy and orientation for disseminating high quality of CESD in UK context. The study is also innovative in employing a less subjective multidimensional quality model for assessing the quality of CESD. 
Our findings have several implications for a number of constituencies. For corporate directors, our results support earlier recommendations in CSR literature that the quality of reporting is a multifaceted concept covering many features such as quality of content, credible content using reporting guidelines and assurance services, and readable content using visual tools (e.g., Helfaya and Kotb, 2016; Michelon et al., 2015). Firms should also consider the beneficial effects of having CSR-oriented directors and board's CSR strategy on their environmental performance. For policy-makers and regulators, our results of a positive link between board's CSR strategy and orientation and the credibility of CESD are mainly relevant as these raise concerns about the reliability of CESD (i.e., adopting reporting guidelines and assurance service). This link is indicative of the trust gap between CSR reporters and users. To decrease this gap, policy-makers and regulators need to set a commonly agreed set of CSR reporting guidelines and assurance standards. Additionally, having women on board brings several advantages to companies; they present new ideas, long-term success, and appear on the multiple 'best' sustainable ranks (Al-Shaer and Zaman, 2016; Brammer et al., 2007; Landry et al., 2016). Regulators and policy-makers could set or reform CG regulations to enhance the board composition and to encompass all aspects of diversity such as gender, age, ethnic group, and educational level. For CSR Scholars, the multi-theoretical perspective and the MQM used in this study could be used to conduct future investigations of the board features and CSR/CG disclosure and performance.

This paper is subject to some limitations as well as future research implications. First, we examine CESD in the UK for a single year. Future research, therefore, could encompass a longitudinal and cross-country sample to provide evidence for the broader applicability of these findings. Second, our analysis is limited to CESD made only in standalone CSR reports or annual reports. Further research might address this issue and focus on examining other outlets of corporate communication such as online reporting (e.g., Li, 2010; Robertson and Samy, 2015). Third, this study also used female directors as a measure of board diversity but does not account for the other measures of diversity. So, future studies could also examine other measures of diversity such as: age, educational level, experience and ethnic group (Seto-Pamies, 2015). In spite of the above limitations, this study contributes to the literature by providing evidence that board's CSR strategy and orientation have a significant positive association with the quality of CESD practices. 


\section{Acknowledgements}

The authors would like to thank the editor (Professor Richard Welford) and the anonymous reviewers of the journal for their constructive comments and valuable suggestions on earlier versions of the paper. The authors also acknowledge the financial support of both Damanhour University and Cairo University, Egypt.

\section{References}

Alberici A, Querci F. 2016. The Quality of Disclosure on Environmental Policy: The Profile of Financial Intermediaries. Corporate Social Responsibility and Environmental Management 23: 283-296.

Al-Shaer H, Zaman M. 2016. Board gender diversity and sustainability reporting quality. Journal of Contemporary Accounting and Economics 12: 210-222.

Al-Tuwaijri S, Christensen T, Hughes H. 2004. The relations among environmental disclosure, environmental performance, and economic performance: a simultaneous equations approach. Accounting, Organisation and Society 29 (5/6): 447-471.

Alrazi B, De Villiers C, Van Staden C. 2016. The environmental disclosures of the electricity generation industry: a global perspective. Accounting and Business Research 46 (6): 665701.

Arena C, Bozzolan S, Michelon G. 2015. Environmental Reporting: Transparency to Stakeholders or Stakeholder Manipulation? An Analysis of Disclosure Tone and the Role of the Board of Directors. Corporate Social Responsibility and Environmental Management 22: 346-361.

Axjonow A, Ernstberger J, Pott C. 2016. The Impact of Corporate Social Responsibility Disclosure on Corporate Reputation: A Non-professional Stakeholder Perspective. Journal of Business Ethics. DOI: 10.1007/s10551-016-3225-4.

Bear S, Rahman N, Post C. 2010. The impact of board diversity and gender composition on corporate social responsibility and firm reputation. Journal of Business Ethics 97(2): 207-221.

Beasley M, Carcello J, Hermanson D, Neal T. 2009. The Audit Committee Oversight Process. Contemporary Accounting Research 26: 65-122.

Beattie V, McInnes B, and Fearnley S. 2004. A methodology for analysing and evaluating narratives in annual reports: A comprehensive descriptive profile and metrics for disclosure quality attributes. Accounting Forum 28(3): 205-236.

Beck A, Campbell D, Shrives P. 2010. Content analysis in environmental reporting research: Enrichment and rehearsal of the method in a British-German context. British Accounting Review 42: 207-222.

Banerjee, B., Iyer, S., \& Kashyap, K. 2003. Corporate Environmentalism: Antecedents and Influence of Industry Type. Journal of Marketing 67 (2): 106-122.

Bear S, Rahman N, and Post C. 2010. The impact of board diversity and gender composition on corporate social responsibility and firm reputation. Journal of Business Ethics 97(2): 207-221.

Ben-Amar W, Chang M, Mcllkenny P. 2016. Board Gender Diversity and Corporate Response to Sustainability Initiatives: Evidence from the Carbon Disclosure Project. Journal of Business Ethics. DOI: 10.1007/s10551-015-2759-1. 
Brammer S, Millington A, Pavelin S. 2007. Gender and Ethnic Diversity Among UK Corporate Boards. Corporate Governance: An International Review 15(2): 393-403.

Brammer S, Pavelin S. 2008. Factors influencing the quality of corporate environmental disclosure. Business Strategy \& the Environment 17(2): 120-136.

Casciaro T, Piskorski M. 2005. Power Imbalance, Mutual Dependence, and Constraint Absorption: A Closer Look at Resource Dependence Theory. Administrative Science Quarterly 50: 167-199.

Cater T, Prasnikar J, Cater B. 2009. Environmental strategies and their motives and results in Slovenian Business Practice. Economic and Business Review 11 (1): 55-74.

Cavana Y, Delahaye L, Sekaran U. 2001. Applied business research: Qualitative and quantitative methods. Queensland: John Wiley and Sons.

Chan K, Li J. 2008. Audit committee and firm value: Evidence on outside top executives as expert-independent directors. Corporate Governance: An International Review 16(1): 16-31.

Chau G, Gray S. J. 2010. Family ownership, board independence and voluntary disclosure: Evidence from Hong Kong. Journal of International Accounting, Auditing and Taxation 19(2): 93-109.

Chauvey J, Giordano-Spring S, Cho C, Patten D. 2015. The Normativity and Legitimacy of CSR Disclosure: Evidence from France. Journal of Business Ethics 130: 789-803.

Cheng E, Courtenay S. 2006. Board composition, regulatory regime and voluntary disclosure. The International Journal of Accounting 41(3), 262-289.

Chen G, Firth M, Gao D, Rui O. 2006. Ownership Structure, Corporate Governance, and Fraud: Evidence from China. Journal of Corporate Finance 12: 424-448.

Chen J. Roberts R. 2010. Toward a More Coherent Understanding of the OrganizationSociety Relationship: A Theoretical Consideration for Social and Environmental Accounting Research. Journal of Business Ethics 97:651-665.

Cho C. 2009. Legitimation Strategies Used in Response to Environmental Disaster: A French Case Study of Total SA's Erika and AZF Incidents. European Accounting Review 18(1): 33-62,

Cho C. Roberts R. 2010. Environmental reporting on the internet by America's Toxic 100: Legitimacy and self-presentation. International Journal of Accounting Information Systems 11: 1- 16.

Cho C, Guidry R, Hageman A, Patten D. 2012a. Do actions speak louder than words? An empirical investigation of corporate environmental reputation. Accounting, Organization and Society 37: 14-25.

Cho C, Michelon G, Patten D. 2012b. Impression management in sustainability reports: An empirical investigation of the use of graphs. Accounting and the Public Interest 12: 1637.

Cho C, Patten D. 2007. The role of corporates as tools of legitimacy: A research note. Accounting, Organisation and Society 32: 639-647.

Clarkson P, Li Y, Richardson G, Vasvari F. 2011. Revisiting the relation between environmental performance and environmental disclosure: An empirical analysis. Accounting, Organisations and Society 33: 303-327.

Clarkson P, Li Y, Richardson G, Vasvari F. 2011. Does it really pay to be green? Determinants and consequences of proactive environmental strategies. Journal of Accounting and Public Policy 30(2): 122-144.

Cooper S, Slack R. 2015. Reporting practice, impression management and company performance: a longitudinal and comparative analysis of water leakage disclosure. Accounting and Business Research 45(6-7): 801-840. 
Cowen S, Ferreri L, Parker L. 1987. The impact of corporate characteristics on social responsibility disclosure: A typology and frequency-based analysis. Accounting, Organizations and Society 12: 111-122.

D’Amico E, Coluccia D, Fontana S, Solimene S. 2016. Factors Influencing Corporate Environmental Disclosure. Business Strategy and the Environment 25: 178-192.

Davis G, Cobb A. 2010. Resource dependence theory: Past and future. Research in the Sociology of Organizations 28: 21- 42.

Deegan C, Rankin M, Tobin J. 2002. An examination of the corporate social and environmental disclosures of BHP from 1983- 1997, a test of legitimacy theory. Accounting, Auditing and Accountability Journal 15(3): 312-343.

Deegan C. 2007. Organizational legitimacy as a motive for sustainability reporting. In Unerman J, Bebbington J, O'Dywer B. (Eds), Sustainability Accounting and Accountability, Routledge: London.

De Villers C, Alexander D. 2014. The institutionalization of corporate social responsibility reporting. British Accounting Review 46: 198-212.

De Villiers C, Naiker V, and Van Staden J. 2011. The effect of board characteristics on firm environmental performance. Journal of Management 37:1636-1663.

Dhaliwal D, Li O, Tsang A, Yang Y. 2014. Corporate social responsibility disclosure and the cost of equity capital: The roles of stakeholder orientation and financial transparency. Journal of Accounting and Public Policy 33(4): 328-355.

Dhaliwal D, Li O, Tsang A, Yang G. 2011. Voluntary nonfinancial disclosure and the cost of equity capital: The initiation of corporate social responsibility reporting. Accounting Review 86 (1): 59-100.

Dhaliwal D, Radhakrishnan S, Tsang A, Yang Y. 2012. Nonfinancial disclosure and analyst forecast accuracy: International evidence on corporate social responsibility disclosure. Accounting Review 87(3): 723-759.

Fifka M. 2013. Corporate Responsibility Reporting and its Determinants in Comparative Perspective- a Review of the Empirical Literature and a Meta-analysis. Business Strategy and the Environment 22: 1-35.

Fraj-Andrés E, Martínez-Salinas E, Matute-Vallejo J. 2009. Factors Affecting Corporate Environmental Strategy in Spanish Industrial Firms. Business Strategy and the Environment 18: 500-514.

FRC. 2014. The UK corporate governance code. London: Financial Reporting Council.

FRC. 2011. Consultation document: Gender diversity on boards. London: Financial Reporting Council.

Guthrie J, Cuganesan S, Ward L. 2008. Industry specific social and environmental reporting: The Australian Food and Beverage Industry. Accounting Forum 32: 1-15.

Galbreath J. 2010. Corporate governance practices that address climate change: An exploratory study. Business Strategy and the Environment 19(5): 335-350.

Gray R, Javad M, Power D, Sinclair D. 2001. Social and Environmental Disclosure and Corporate Characteristics: A Research Note and Extension. Journal of Business Finance and Accounting 28(3): 327-356.

Gray R, Kouhy R, Lavers S. 1995. Corporate social and environmental reporting: a review of the literature and a longitudinal study of UK disclosure. Accounting, Auditing and Accountability Journal 8(2):47-77.

Global Reporting Initiative (GRI). 2006. Sustainability reporting guidelines: RG global reporting initiatives.https://www.globalreporting.org/resourcelibrary/G3-GuidelinesIncl-Technical-Protocol.pdf [15 Sep 2015].

Gujarati N. (2003). Basic econometrics. New York: McGraw-Hill. 
Haniffa R. Cooke T. 2005. The impact of culture and governance on corporate social reporting. Journal of Accounting and Public Policy 24: 391-430.

Haque S, Deegan, C, Inglis, R. 2016. Demand for, and impediments to, the disclosure of information about climate change-related corporate governance practices. Accounting and Business Research 46(6): 620- 664.

Harjoto M, Jo H. 2011. Corporate governance and CSR nexus. Journal of Business Ethics 100(1): 45-67.

Hart S. 1995. A natural resource based view of the firm. Academy of Management Review 20(4): 986-1014.

Helfaya A. 2012. Assessing the measurement of quality of corporate environmental reporting: UK Evidence. PhD. University of Aberdeen, UK.

Helfaya A, Kotb A. 2016. Environmental Reporting Quality: An Analysis of Global Creditability Initiatives. In M. Erdogdu, T. Arun, I. Ahmad, Handbook of Research on Green Economic Development Initiatives and Strategies (pp. 628-657). IGI Global.

Hillman A, Cannella A, Harris I. 2002. Women and racial minorities in the boardroom: How do directors differ? Journal of Management 28(6): 747-763.

Hillman A, Dalziel T. 2003. Boards of directors and firm performance: Integrating agency and resource dependence perspectives. Academy of Management Review 28(3): 383396.

Hillman A, Withers M, Collins B. 2009. Resource dependence theory: a review. Journal of Management 35(6): 1404-1427.

Hoechle D. 2007. Robust standard errors for panel regressions with cross-sectional dependence. Stata Journal 7, 281-312.

Jizi M, Salama A, Dixon R, Stratling R. 2014. Corporate Governance and Corporate Social Responsibility Disclosure: Evidence from the US Banking Sector. Journal of Business Ethics 125: 601-615.

Khan A, Muttakin M, Siddiqui J. 2013. Corporate governance and corporate social responsibility: Evidence from an emerging economy. Journal of Business Ethics 114(2): 207-223.

Kolk A, Walhain S, Van der Wateringen S. 2001. Environmental reporting by the Fortune Global 250: Exploring the influence of nationality and sector. Business Strategy and the Environment 10: 15-28.

KPMG. 2013. KPMG International Survey of Corporate Responsibility Reporting. KPMG Sustainability Services, Netherlands. https://home.kpmg.com/xx/en/home/insights/2013/12/kpmg-survey-corporateresponsibility-reporting-2013.html [10 May 2015].

Krippendorff K. 2004. Content analysis: An introduction to its methodology, London: SAGE.

Landry E, Benardi R, Bosco S. 2016. Recognition for Sustained Corporate Social Responsibility: Female Directors Make a Difference. Corporate Social Responsibility and Environmental Management 23: 27-36.

Liao L, Luo L, Tang Q. 2015. Gender diversity, board independence, environmental committee and greenhouse gas disclosure. British Accounting Review 47: 409-424.

Liao L, Lin T, Zhang Y. 2016. Corporate Board and Corporate Social Responsibility Assurance: Evidence from China. Journal of Business Ethics. DOI: 10.1007/s10551016-3176-9

Lock I, Seele P. 2015. Analysing Sector-Specific CSR Reporting: Social and Environmental Disclosure to Investors in the Chemicals and Banking and Insurance Industry. Corporate Social Responsibility and Environmental Management 22: 113-128. 
Lu Y, Abeysekera I. 2014. Stakeholders' power, corporate characteristics, and social and environmental disclosure: evidence from China. Journal of Cleaner Production 64: 426-436.

Mahoney L, Thorne L, Cecil L, LaGore W. 2013. A research note on standalone corporate social responsibility reports: Signaling or greenwashing? Critical Perspectives on Accounting 24 (4/5): 350-359.

Mallin C, Michelon G. 2011. Board reputation attributes and corporate social performance: An empirical investigation of the US Best Corporate Citizens. Accounting and Business Research 41(2): 119-144.

Mallin C, Michelon G, Raggi D. 2013. Monitoring intensity and stakeholders' orientation: How does governance affect social and environmental disclosure? Journal of Business Ethics 114(1): 29-43.

Martensson K, Westerberg K. 2016. Corporate Environmental Strategies Towards Sustainable Development. Business Strategy and the Environment 25: 1-9.

Martinez-Ferrero J, Ruiz-Cano D, Garcia-Sanchez I. 2016. The Causal Link between Sustainable Disclosure and Information Asymmetry: The Moderating Role of the Stakeholder Protection Context. Corporate Social Responsibility and Environmental Management 23: 319-332.

Menguc B, Auh S, Ozanne L. 2010. The interactive effect of internal and external factors on a proactive environmental strategy and its influence on a firm's performance. Journal of Business Ethics 94: 279-298.

Michelon G, Pilonato S, Ricceri F. 2015. CSR reporting practices and the quality of disclosure: An empirical analysis. Critical Perspectives on Accounting 33: 59-78.

Neugebauer F, Figge F, Hahn T. 2016. Planned or Emergent Strategy Making? Exploring the Formation of Corporate Sustainability Strategies. Business Strategy and the Environment 25: 323-336.

Nielsen S, Huse M. 2010. The contribution of women on boards of directors: Going beyond the surface. Corporate Governance: An International Review 18(2): 136-148.

Patten D, Zhao N. 2014. Standalone CSR reporting by U.S. retail companies. Accounting Forum 38: 132-144.

Peni E, Vähämaa S. 2012. Did good corporate governance improve bank performance during the financial crisis? Journal of Financial Services Research 41, 19-35.

Pfeffer J, Salancik G. 1978. The external control of organizations: A resource dependence perspective. New York: Harper and Row.

Peters F, Romi M. 2014. Does the voluntary adoption of corporate governance mechanisms improve environmental risk disclosures? Evidence from greenhouse gas emission accounting. Journal of Business Ethics 125(4): 637-666.

Peters F, Romi, M. 2015. The Association between Sustainability Governance Characteristics and the Assurance of Corporate Sustainability Reports. Auditing: A Journal of Practice and Theory 34 (1): 163-198.

Post C, Rahman N, Rubow E. 2011. Green governance: boards of directors' composition and environmental corporate social responsibility. Business and Society 50(1): 189-223.

Prado-Lorenzo J, Garcia-Sanchez I. 2010. The role of the board of directors in disseminating relevant information on greenhouse gases. Journal of Business Ethics 97(3): 391-424.

Qiu Y, Shaukat A, Tharyan, R. 2016. Environmental and social disclosures: Link with corporate financial performance. British Accounting Review 48: 102-116

Robertson F, Samy M. 2015. Factors affecting the diffusion of integrated reporting- a UK FTSE100 perspective. Sustainability Accounting, Management and Policy Journal 6(2): 190-223. 
Rodrigue M, Mangan M, Cho C. 2013. Is environmental governance substantive or symbolic? An empirical investigation. Journal of Business Ethics 114(1): 107-129.

Samkin G, Schneider A. 2010. Accountability, narrative reporting and legitimation: The case of a New Zealand public benefit entity. Accounting, Auditing and Accountability Journal 23(2), 256-289

Schwartz M. 2005. Universal Moral Values for Corporate Codes of Ethics. Journal of Business Ethics 59: 27-44.

Sheridan A. 2001. A view from the top: Women on the boards of public companies. Corporate Governance 1(1): 8-14.

Seto-Pamies D. 2015. The Relationship between Women Directors and Corporate Social Responsibility. Corporate Social Responsibility and Environmental Management 22: 334-345.

Shaukat A, Qiu Y, Trojanowski G. 2016. Board Attributes, Corporate Social Responsibility Strategy, and Corporate Environmental and Social Performance. Journal of Business Ethics 135: 569-585.

Schnittfeld N, Busch T. 2016. Sustainability Management within Supply Chains- A Resource Dependence View. Business Strategy and the Environment 25: 337-354.

Smith R. 2003. Audit Committees Combined Code Guidance. London: Financial Reporting Council.

Solomon A, Lewis A. 2002. Incentives and disincentives for corporate environmental disclosure. Business Strategy and the Environment 11: 154-169.

Srinidhi B, Gul A, Tsui J. 2011. Female directors and earnings quality. Contemporary Accounting Research 28 (5):1610-1644.

Suchman M. 1995. Managing legitimacy: Strategic and Institutional Approaches. Academy of Management Review 20(3): 571-610.

Tauringana V, Chithambo L. 2015. The effect of DEFRA guidance on greenhouse disclosure. British Accounting Review 47(4): 425-444.

Thorne L, Mahoney L, Manetti G. 2014. Motivations for issuing standalone CSR reports: A survey of Canadian firms. Accounting Auditing and Accountability Journal 27 (4): 686714.

Unerman J, Bebbington J, O’Dwyer B. 2007. Introduction to sustainability accounting and accountability. In J. Unerman, J. Bebbington, B. O'Dwyer (Eds.), Sustainability accounting and accountability (pp. 1-16). London: Routledge.

Van Staden C, Hooks J. 2007. A comprehensive comparison of corporate environmental reporting and responsiveness. British Accounting Review 39: 197-210.

Wegener M, Elayan F, Felton S, Li J. 2013. Factors influencing corporate environmental disclosures. Accounting Perspectives 12(1): 53-73

Wooldridge M. 2010. Econometric analysis of cross section and panel data. Massachusetts: MIT Press. 
Table 1: Sample distribution

Panel (A) Sample selection

UK FTSE 100 companies

100

Less

Firms with missing stand-alone CSR reports/annual reports or complete data

(6)

Total final sample

94

Panel (B) Industry composition

\begin{tabular}{ll}
\hline Industry & $\begin{array}{l}\text { Number of } \\
\text { firms }(\%)\end{array}$ \\
\hline Oil and Gas & $7(7)$ \\
Basic Materials & $11(12)$ \\
Industrials & $13(14)$ \\
Consumer Goods & $8(9)$ \\
Health Care & $4(4)$ \\
Consumer Services & $15(16)$ \\
Telecommunications & $4(4)$ \\
Utilities & $6(6)$ \\
Financials & $22(23)$ \\
Technology & $4(4)$ \\
Total & $94(100)$
\end{tabular}


Table 2: Descriptive statistics

\begin{tabular}{|c|c|c|c|c|c|}
\hline Variables & Mean & Median & Std. Dev. & Min. & Max. \\
\hline QUAN_ED (\%) & 24.15 & 25 & 18.63 & .17 & 100 \\
\hline QUAL_ED (\%) & 46.08 & 45.18 & 21.02 & 9.16 & 83.99 \\
\hline CON_ED & 26.68 & 27.66 & 8.02 & 5.1 & 43.01 \\
\hline CRE_ED & 15.68 & 16 & 13.74 & 0 & 31 \\
\hline COM_ED & 3.72 & 3.44 & 3.01 & 0 & 13 \\
\hline BCSRS (\%) & 84.35 & 91.85 & 15.88 & 9.96 & 94.37 \\
\hline BCSRO & 2.104 & 2 & 0.8643 & 0 & 3 \\
\hline $\operatorname{INDED}(\%)$ & 56.01 & 54.11 & 15.01 & 24.17 & 91.36 \\
\hline FEMD $(\%)$ & 12.60 & 11.11 & 9.74 & 0 & 42.86 \\
\hline ACFEX (\%) & 65.40 & 73.9 & 22.60 & 5.92 & 73.90 \\
\hline CSRC & 0.6875 & 1 & 0.4660 & 0 & 1 \\
\hline SCSRR & 0.7475 & 1 & 0.4367 & 0 & 1 \\
\hline $\operatorname{SHOLD}(\%)$ & 14.27 & 7 & 19.42 & 0 & 79 \\
\hline DUALITY & 0.0204 & 0 & 0.1421 & 0 & 1 \\
\hline FSIZE (£ m) & 89.05 & 9.131 & 278.17 & 1.01 & 1576.30 \\
\hline ROA (\%) & 6.76 & 5.99 & 5.57 & -4.69 & 29.15 \\
\hline $\operatorname{LEV}(\%)$ & 18.15 & 16.65 & 14.24 & 0 & 55.16 \\
\hline SLACK (\%) & 11.00 & 8.099 & 10.86 & .81 & 66.53 \\
\hline CAPEX (\%) & 4.17 & 2.607 & 4.32 & 0 & 20.60 \\
\hline
\end{tabular}

Notes: Variables are defined as follows: quantity of environmental sustainability disclosure score (QUAN_ED); quality of environmental sustainability disclosure score (QUAL_ED); content sub-index of environmental sustainability disclosure quality (CON_ED); credibility sub-index of environmental sustainability disclosure quality (CRE_ED); communication sub-index of environmental sustainability disclosure quality (COM_ED); board's CSR strategy (BCSRS); board's CSR orientation (BCSRO); board independence (INDED); board gender diversity (FEMD); audit committee financial expertise (ACFEX); CSR committee (CSRC); issuance of a standalone CSR report (SCSRR); block shareholdings (SHOLD); CEO duality (DUALITY); firm size (FSIZE); return on assets (ROA); firm leverage (LEV); financial slack (SLACK); and capital expenditure (CAPEX). 
Table 3: Correlation matrix

\begin{tabular}{|c|c|c|c|c|c|c|c|c|c|c|c|c|c|c|c|c|}
\hline & (1) & (2) & (3) & (4) & (5) & (6) & (7) & (8) & (9) & (10) & (11) & (12) & (13) & (14) & (15) & (16) \\
\hline QUAN_ED (1) & 1.00 & & & & & & & & & & & & & & & \\
\hline QUAL_ED (2) & $\begin{array}{l}0.62 \\
(0.00)\end{array}$ & 1.00 & & & & & & & & & & & & & & \\
\hline CON_ED (3) & $\begin{array}{l}0.78 \\
(0.00)\end{array}$ & $\begin{array}{l}0.84 \\
(0.00)\end{array}$ & 1.00 & & & & & & & & & & & & & \\
\hline CRE_ED (4) & $\begin{array}{l}0.30 \\
(0.00)\end{array}$ & $\begin{array}{l}0.90 \\
(0.00)\end{array}$ & $\begin{array}{l}0.54 \\
(0.00)\end{array}$ & 1.00 & & & & & & & & & & & & \\
\hline COM_ED (5) & $\begin{array}{l}0.85 \\
(0.00)\end{array}$ & $\begin{array}{l}0.62 \\
(0.00)\end{array}$ & $\begin{array}{l}0.72 \\
(0.00)\end{array}$ & $\begin{array}{l}0.31 \\
(0.00)\end{array}$ & 1.00 & & & & & & & & & & & \\
\hline BCSRS (6) & $\begin{array}{l}0.40 \\
(0.04)\end{array}$ & $\begin{array}{l}0.45 \\
(0.00)\end{array}$ & $\begin{array}{l}0.41 \\
(0.00)\end{array}$ & $\begin{array}{l}0.36 \\
(0.00)\end{array}$ & $\begin{array}{l}0.36 \\
(0.08)\end{array}$ & 1.00 & & & & & & & & & & \\
\hline BCSRO (7) & $\begin{array}{l}0.25 \\
(0.01)\end{array}$ & $\begin{array}{l}0.47 \\
(0.00)\end{array}$ & $\begin{array}{l}0.32 \\
(0.00)\end{array}$ & $\begin{array}{l}0.47 \\
(0.00)\end{array}$ & $\begin{array}{l}0.27 \\
(0.00)\end{array}$ & $\begin{array}{l}0.10 \\
(0.33)\end{array}$ & 1.00 & & & & & & & & & \\
\hline $\operatorname{CSRC}(8)$ & $\begin{array}{l}0.44 \\
(0.00)\end{array}$ & $\begin{array}{l}0.63 \\
(0.01)\end{array}$ & $\begin{array}{l}0.62 \\
(0.20)\end{array}$ & $\begin{array}{l}0.50 \\
(0.00)\end{array}$ & $\begin{array}{l}0.46 \\
(0.00)\end{array}$ & $\begin{array}{l}0.48 \\
(0.00)\end{array}$ & $\begin{array}{l}0.21 \\
(0.04)\end{array}$ & 1.00 & & & & & & & & \\
\hline SCSRR (9) & $\begin{array}{l}0.69 \\
0.00\end{array}$ & $\begin{array}{l}0.64 \\
0.00\end{array}$ & $\begin{array}{l}0.69 \\
0.00\end{array}$ & $\begin{array}{l}0.43 \\
0.00\end{array}$ & $\begin{array}{l}0.66 \\
0.00\end{array}$ & $\begin{array}{l}0.51 \\
0.00\end{array}$ & $\begin{array}{l}0.18 \\
0.08\end{array}$ & $\begin{array}{l}0.47 \\
0.00\end{array}$ & 1.00 & & & & & & & \\
\hline SHOLD (10) & $\begin{array}{l}-0.06 \\
(0.58)\end{array}$ & $\begin{array}{l}0.07 \\
(0.49)\end{array}$ & $\begin{array}{l}0.07 \\
(0.51)\end{array}$ & $\begin{array}{l}0.06 \\
(0.54)\end{array}$ & $\begin{array}{l}0.02 \\
(0.85)\end{array}$ & $\begin{array}{l}-0.11 \\
(0.29)\end{array}$ & $\begin{array}{l}-0.13 \\
(0.22)\end{array}$ & $\begin{array}{l}0.15 \\
(0.16)\end{array}$ & $\begin{array}{l}-0.11 \\
(0.27)\end{array}$ & 1.00 & & & & & & \\
\hline DUALITY (11) & $\begin{array}{l}0.21 \\
0.04\end{array}$ & $\begin{array}{l}-0.02 \\
0.83\end{array}$ & $\begin{array}{l}0.03 \\
0.81\end{array}$ & $\begin{array}{l}-0.08 \\
0.44\end{array}$ & $\begin{array}{l}0.14 \\
0.17\end{array}$ & $\begin{array}{l}-0.03 \\
0.74\end{array}$ & $\begin{array}{l}0.15 \\
0.14\end{array}$ & $\begin{array}{l}-0.06 \\
0.57\end{array}$ & $\begin{array}{l}-0.08 \\
0.43\end{array}$ & $\begin{array}{l}-0.01 \\
0.89\end{array}$ & 1.00 & & & & & \\
\hline FSIZE (12) & $\begin{array}{l}0.00 \\
0.96\end{array}$ & $\begin{array}{l}0.16 \\
0.12\end{array}$ & $\begin{array}{l}0.06 \\
0.58\end{array}$ & $\begin{array}{l}0.21 \\
0.03\end{array}$ & $\begin{array}{l}-0.03 \\
0.75\end{array}$ & $\begin{array}{l}0.15 \\
0.14\end{array}$ & $\begin{array}{l}0.10 \\
0.32\end{array}$ & $\begin{array}{l}0.17 \\
0.10\end{array}$ & $\begin{array}{l}0.12 \\
0.24\end{array}$ & $\begin{array}{l}0.11 \\
0.27\end{array}$ & $\begin{array}{l}-0.04 \\
0.69\end{array}$ & 1.00 & & & & \\
\hline ROA (13) & $\begin{array}{l}-0.11 \\
(0.26)\end{array}$ & $\begin{array}{l}0.00 \\
(0.97)\end{array}$ & $\begin{array}{l}-0.05 \\
(0.61)\end{array}$ & $\begin{array}{l}0.06 \\
(0.52)\end{array}$ & $\begin{array}{l}-0.13 \\
(0.19)\end{array}$ & $\begin{array}{l}-0.11 \\
(0.26)\end{array}$ & $\begin{array}{l}0.07 \\
(0.47)\end{array}$ & $\begin{array}{l}-0.04 \\
(0.70)\end{array}$ & $\begin{array}{l}-0.17 \\
(0.10)\end{array}$ & $\begin{array}{l}0.18 \\
(0.08)\end{array}$ & $\begin{array}{l}0.00 \\
(0.98)\end{array}$ & $\begin{array}{l}-0.32 \\
(0.00)\end{array}$ & 1.00 & & & \\
\hline LEV (14) & $\begin{array}{l}0.10 \\
0.35\end{array}$ & $\begin{array}{l}0.08 \\
0.46\end{array}$ & $\begin{array}{l}0.19 \\
0.06\end{array}$ & $\begin{array}{l}-0.03 \\
0.78\end{array}$ & $\begin{array}{l}0.15 \\
0.14\end{array}$ & $\begin{array}{l}0.13 \\
0.22\end{array}$ & $\begin{array}{l}0.04 \\
0.73\end{array}$ & $\begin{array}{l}0.08 \\
0.45\end{array}$ & $\begin{array}{l}0.15 \\
0.13\end{array}$ & $\begin{array}{l}-0.22 \\
0.03\end{array}$ & $\begin{array}{l}0.15 \\
0.13\end{array}$ & $\begin{array}{l}-0.20 \\
0.05\end{array}$ & $\begin{array}{l}-0.05 \\
0.60\end{array}$ & 1.00 & & \\
\hline SLACK (15) & $\begin{array}{l}-0.19 \\
0.07\end{array}$ & $\begin{array}{l}-0.18 \\
0.08\end{array}$ & $\begin{array}{l}-0.23 \\
0.02\end{array}$ & $\begin{array}{l}-0.11 \\
0.30\end{array}$ & $\begin{array}{l}-0.15 \\
0.14\end{array}$ & $\begin{array}{l}-0.08 \\
0.43\end{array}$ & $\begin{array}{l}-0.17 \\
0.09\end{array}$ & $\begin{array}{l}-0.06 \\
0.54\end{array}$ & $\begin{array}{l}-0.13 \\
0.19\end{array}$ & $\begin{array}{l}0.09 \\
(0.40)\end{array}$ & $\begin{array}{l}-0.06 \\
(0.53)\end{array}$ & $\begin{array}{l}-0.17 \\
(0.09)\end{array}$ & $\begin{array}{l}0.16 \\
(0.13)\end{array}$ & $\begin{array}{l}-0.13 \\
(0.20)\end{array}$ & 1.00 & \\
\hline CAPEX (16) & $\begin{array}{l}0.01 \\
(0.92)\end{array}$ & $\begin{array}{l}0.04 \\
(0.68)\end{array}$ & $\begin{array}{l}0.01 \\
(0.93)\end{array}$ & $\begin{array}{l}0.06 \\
(0.54)\end{array}$ & $\begin{array}{l}-0.01 \\
(0.90)\end{array}$ & $\begin{array}{l}0.05 \\
(0.60)\end{array}$ & $\begin{array}{l}0.03 \\
(0.75)\end{array}$ & $\begin{array}{l}0.12 \\
(0.23)\end{array}$ & $\begin{array}{l}-0.09 \\
(0.37)\end{array}$ & $\begin{array}{l}0.26 \\
(0.01)\end{array}$ & $\begin{array}{l}0.10 \\
0.35\end{array}$ & $\begin{array}{l}-0.23 \\
0.02\end{array}$ & $\begin{array}{l}0.33 \\
(0.00)\end{array}$ & $\begin{array}{l}0.00 \\
(0.99)\end{array}$ & $\begin{array}{l}0.01 \\
(0.96)\end{array}$ & 1.00 \\
\hline
\end{tabular}

Notes: Table 2 fully defines all the variables used. P-values are in parentheses. 
Table 4: OLS regression results of CESD

\begin{tabular}{|c|c|c|c|c|c|c|}
\hline $\begin{array}{l}\text { Indep. and control variables } \\
\text { (Model) }\end{array}$ & $\begin{array}{l}\text { Expected } \\
\text { Sign }\end{array}$ & $\begin{array}{l}\text { QUAN_ED } \\
\text { (1) }\end{array}$ & $\begin{array}{l}\text { QUAL_ED } \\
\text { (2) }\end{array}$ & $\begin{array}{l}\text { CON_ED } \\
\text { (3) }\end{array}$ & $\begin{array}{l}\text { CRE_ED } \\
\text { (4) }\end{array}$ & $\begin{array}{l}\text { COM_ED } \\
\text { (5) }\end{array}$ \\
\hline BCSRS & + & .043 & $.208 * *$ & .063 & $.242 * * *$ & -.001 \\
\hline BCSRO & + & .134 & $.296 * * *$ & $.194 * *$ & $.275 * * *$ & $.163 *$ \\
\hline CSRC & + & $.412 * *$ & $.566 * * *$ & $.594 * * *$ & .248 & $.478 * *$ \\
\hline SCSRR & + & $1.234 * * *$ & $.728 * * *$ & $.878 * * *$ & .225 & $1.283 * * *$ \\
\hline SHOLD & $+/-$ & -.092 & $-.202 * *$ & $-.197 *$ & -.163 & $.210^{*}$ \\
\hline DUALITY & $+/-$ & .521 & -.316 & .252 & $-.430 *$ & .706 \\
\hline FSIZE & $+/-$ & -.050 & -.043 & .040 & -.004 & -.046 \\
\hline ROA & + & .072 & .045 & .078 & .024 & -.025 \\
\hline LEV & + & .008 & .006 & .001 & -.006 & .039 \\
\hline SLACK & + & .014 & .031 & .016 & .007 & $.056^{*}$ \\
\hline CAPEX & + & .011 & $.031 *$ & .012 & .023 & .007 \\
\hline Industry effects & & Included & Included & Included & Included & Included \\
\hline Intercept & & $-1.231 * * *$ & $-.758 * * *$ & $-1.163 * * *$ & .174 & $-1.670 * * *$ \\
\hline$R$-squared & & 0.69 & 0.75 & 0.68 & 0.66 & 0.68 \\
\hline$F$-Statistic & & $11.46 * * *$ & $10.84 * * *$ & $10.75 * * *$ & $19.35 * * *$ & $12.50 * * *$ \\
\hline$V I F$ & & 2.11 & 2.11 & 2.11 & 2.11 & 2.11 \\
\hline$N$ & & 94 & 94 & 94 & 94 & 94 \\
\hline
\end{tabular}

$*, * *$, and $* * *$ indicate significance at $1 \%, 5 \%$, and $10 \%$, respectively (all two tailed).

All variables are fully defined in Table 2 . 